- підвищення кваліфікації педагогів у питанні формування управлінської підготовки майбутніх офіцерів пожежної безпеки, навчально-методичне забезпечення та супроводження ними самостійної роботи курсантів.

Перспективні напрями подальших наукових пошуків: обгрунтування міждисциплінарної методики формування управлінської компетентності майбутніх офіцерів пожежної безпеки в процесі професійної підготовки.

\title{
Література
}

1. Новиков А. М. Методология научного исследования : [учебно-метод. пособие] / А. М. Новиков, Д. А. Новиков. - М. : Либроком, 2010. - 280 с. 2. Наказ Міністерства України з питань надзвичайних ситуацій та у справах захисту населення від наслідків Чорнобильської катастрофи з 01.12.2009 № 808 «Про затвердження Довідника кваліфікаційних характеристик професій працівників МНС України»[Електронний ресурс]. - Режим доступу: http://zakon.nau.ua/doc/?uid=1041.38208.1\&nobreak=1

УДК 37.016:51

\author{
В. В. Корольський, \\ кандидат техн. наук, професор, \\ A. М. Капіносов, \\ кандидат пед. наук, ст. викладач, \\ Криворізький педагогічний інститут \\ ДВНЗ «Криворізький національний університет»
}

\section{МАТЕМАТИЧНА АЛГОРИТМІЧНА КОМПЕТЕНТНІСТЬ: ТЕОРЕТИКО-МЕТОДИЧНІ ОСНОВИ ФОРМУВАННЯ, СТРУКТУРА ТА РІВНІ}

Корольський В. В., Капіносов А. М. Математична алгоритмічна компетентність: теоретикометодичні основи формування, структура та рівні.

У статті розкрито теоретико-методичні основи формування алгоритмічної компетентності як виду математичної компетентності, визначено її структуру і рівні.

Ключові слова: математична компетентність, алгоритмічна компетентність, алгоритм, алгоритмічне мислення, алгоритмічна культура, структура алгоритмічної компетентності, рівні алгоритмічної компетентності.

Корольський В. В., Капиносов А. Н. Математическая алгоритмическая компетентность: теоретико-методические основы формирования, структура и уровни.

В статье раскрыты теоретико-методические основы формирования алгоритмической компетентности как вида математической компетентности, определены ее структура и уровни.

Ключевые слова: математическая компетентность, алгоритмическая компетентность, алгоритм, алгоритмическое мышление, алгоритмическая культура, структура алгоритмической компетентности, уровни алгоритмической компетентности.

Korolsky V. V. Kapinosov A. M. Algorithmic mathematical competence: theoretical and methodological basis for the formation, structure and levels.

The article presents theory-and-methodological bases for the formationof algorithmic competenceas a type of mathematical competence is closed its structure and levels.

Key words: mathematical competence, algorithmic competence, algorithm, algorithmic thinking,algorithmic culture, the structure of algorithmic competenc elevels of algorithmic competence.

Розбудова математичної освіти на засадах компетентнісного підходу передбачає виокремлення видів математичної предметної компетентності, розкриття їх структури, рівнів та розроблення теоретико-методичних основ формування.

У науково-методичній літературі виокремлено п’ять складників математичної компетентності: понятійна, алгоритмічна (процедурна), дослідницька, технологічна i методологічна компетентності. Їх характеристики, показники вияву подано у працях Ю. Захарійченка, О. Школьного [3], М. Зелмана, О. Ляшенко, С. Ракова [7]. Водночас структура, рівні названих вище компетенцій не розглядалися. Крім того, деякі з видів 
компетенцій трактуються досить вузько. Так, алгоритмічна компетентність часто ототожнюється лише з умінням розв'язувати типові задачі [7]. У зв'язку з цим актуальним вважаємо завдання надати більш повну характеристику видів математичної компетентності, розробити їх структуру за схемою, запропонованою А. Хуторським, а саме: 1) типи компетентностей; 2) сфери компетентностей; 3) предметні знання; 4) предметні уміння; 5) досвід пізнавальної діяльності; 6) спосіб діяльності; 7) смислові орієнтації цінностей [10], а також описати рівні сформованості компетентностей.

Mema cmammi: висвітлити теоретико-методичні основи формування алгоритмічної компетентності, іï структуру й рівні.

Характеристика алгоритмічної компетентності. Вихідним як у характеристиці алгоритмічної компетентності, так і їі формування є поняття алгоритму.

Алгоритм є одним із видів методів діяльності взагалі, а не тільки діяльності розумової, тобто термін використовується не тільки щодо діяльності, яка здійснюється засобами розумових операцій, а й щодо діяльності, що здійснюється засобами практичних, фізичних дій. Водночас поняття алгоритму є фундаментальним математичним поняттям, продуктом людської діяльності. Алгоритми виникли в математиці й використовуються в ній протягом всього часу їі існування. Науковці Ю. Макаренков та А. Столяр підкреслюють, що алгоритми виникли як відповіді на питання: «Чи існує загальний метод, який дозволяє для будь-якої окремої задачі певного класу в скінченне число кроків надати необхідну відповідь?»[8, с. 8-9].

Під алгоритмом зазвичай розуміють точний, зрозумілий припис про виконання в певній послідовності кроків (дій; операцій) для розв'язування будь-якої із задач, яка належить до певного класу (типу) задач. Ця характеристика не є точним математичним визначенням, проте вона досить ясно розкриває сутність цього поняття й цілком збігається 3 прийнятими в математиці тлумаченнями. Наприклад, відомий математик А. Ляпунов так визначає алгоритм: «Алгоритмом для розв'язування запропонованої задачі називають об'єднання елементарних актів і перевірних умов, яке забезпечує такий порядок роботи (тобто перевірка умов і виконання елементарних актів), який за будь-яких початкових даних, тобто вихідної інформації, зумовлює правильну відповідь» [9, с. 68].

У науковій літературі [6; 8; 9] виокремлють п’ять ознак - необхідних істотних властивостей, за яких певний припис діяльності можна назвати алгоритмом:

1) масовість - алгоритм призначений для розв'язування не однієї задачі, а будь-якої задачі певного класу однотипних задач;

2) дискретність і детермінованість - для кожного кроку (крім останнього) можна вказати єдиний (для деякого набору вихідних об'єктів), безпосередньо наступний за ними крок, між якими немає інших кроків;

3) результативність - алгоритм «гарантує» отримання результату, тобто точне виконання всіх указаних кроків з урахуванням іiї умов і порядку завжди зумовлює успішне розв'язання будь-якої задачі деякого типу;

4) конструктивність - однозначне пізнавання (впізнавання чи розпізнавання, тобто розрізнювання й ототожнення) тих об'єктів, над якими здійснюються кроки алгоритму. У математичних алгоритмах ця вимога забезпечується через фіксацію сукупності об'єктів деякого стандартного виду, відносно яких природно вважати, що їх розрізнювання i ототожнювання не пов'язано з труднощами й відбувається на рівні наочного сприйняття та інтуїтивної очевидності;

5) елементарність, автоматизованість - операції, системи операцій, що складають кожний крок алгоритму, входять до системи набутих, значною мірою автоматизованих дій виконавця алгоритму, тобто є раніше засвоєними елементами алгоритмічної діяльності, $\mathrm{i}$ їх виконання не викликає труднощів.

Теоретичною основою математичних алгоритмів є елементи математичних теорій означення, аксіоми, теореми. Основою встановлення послідовності кроків може бути як окреме теоретичне положення, так і їх синтез. У першому випадку можна говорити про 
алгоритм дії, або алгоритмічну дію, а в другому - про алгоритм задачі, або алгоритмічну задачу.

Важливою характеристикою алгоритмів $є$ способи їх задання. У науково-методичній літературі виокремлюють два основні способи задання алгоритмів: розгорнутий і згорнутий. Розгорнутий спосіб задання алгоритму - це його задання у вигляді словесної програми припису, у якому чітко фіксується, виокремлюється кожний крок і умови його виконання. Згорнуте задання алгоритму - це його задання у формі правила, інструкції, таблиці або формули, у яких не виокремлена послідовність кроків.

Алгоритм, заданий у формі словесної, розгорнутої програми « <..> становить уже готову програму діяльності 3 розв'язування задач, між тим як алгоритми, задані як формули, правила тощо, такою програмою не $\epsilon$, у них ця програма тільки задана, але не дана» [9, с. 71]. Людині, яка здійснює свою діяльність за формулою, таблицею, правилом тощо, потрібно ще виявити і скласти цю програму діяльності. Як приклад згорнутого алгоритму можна навести означення похідної функції в точці, яке тільки задає програму знаходження похідної за приростами, яка в подальшому може бути розгорнутою в алгоритмічний покроковий припис.

Однак, як зауважує Л. Фрідман, відмінність між способами задання алгоритму «<..> не є принциповою, оскільки незалежно від того, у якій формі задано алгоритм, діяльність 3 розв'язування задач відповідно до цього алгоритму буде мати алгоритмічний характер» [9, c. 71].

Класифікація алгоритмів. Залежно від мети, що досягається за допомогою алгоритмів, виокремлюють такі типи математичних алгоритмів: алгоритми розпізнавання, обчислювальні алгоритми, алгоритми перетворення й алгоритми побудови. Якщо завершальним результатом застосування алгоритму $\epsilon$ судження розпізнавання про належність вихідного об'єкту до деякого класу (типу $x \in \mathrm{A}$, де $x$ - вихідний об'єкт класу), то цей алгоритм загалом $€$ алгоритмом розпізнавання. Теоретичною основою алгоритмів розпізнавання $\epsilon$ математичні означення й теореми-ознаки. Як окремі кроки, операції алгоритми розпізнавання можуть передбачати числові операції, вимірювальні операції, перетворення і побудови об'єктів. У числових алгоритмах завершальним результатом застосування числових алгоритмів є отримання кількісних характеристик вихідних об'єктів, значень величин. Зауважимо, що джерелом поняття алгоритм у математиці були насамперед арифметичні дії. Цілком природно, що у формуванні уявлень про алгоритми, виробленні початкового досвіду алгоритмічної діяльності важлива роль належить алгоритмам арифметичних дій. В алгоритмах перетворення й побудови об'єктів завершальними результатами їх застосування є відповідним перетворення вихідних об'єктів чи побудова об'єктів. Прикладами алгоритмів побудови $є$ алгоритми побудови геометричних фігур із заданими властивостями чи за допомогою визначеного інструментарію, алгоритми побудови графіків функцій, математичних моделей реальних процесів. Алгоритмам перетворень належить чільне місце у шкільному курсі алгебри. Основний спосіб їх задання формульний.

Важливими поняттями у характеристиці алгоритмічної компетентності $€$ поняття «алгоритмічне мислення» і поняття «алгоритмічна культура». У науково-методичній літературі основною ознакою алгоритмічного мислення вважається здатність до конструювання алгоритмів. А. Копаєв визначає алгоритмічне мислення як «систему мисленнєвих способів дій, прийомів, методів і відповідних їм мисленнєвих стратегій, які спрямовані на розв'язування як теоретичних, так і практичних задач і результатом яких $\epsilon$ алгоритми як специфічні продукти людської діяльності» [5, с. 1].

Формування алгоритмічного мислення перебуває у тісному взаємозв'язку 3 формуванням загального уміння розв'язувати задачі. Оскільки, щоб задати загальний спосіб розв'язування класу задач у вигляді алгоритму, потрібно спочатку знайти загальний спосіб, а потім дослідити можливість опису цього способу у вигляді конструктивних, однозначно зрозумілих послідовних кроків. Зауважимо, що на засадах зарахування алгоритмічного 
мислення до структури математичної алгоритмічної компетентності побудовані програми 3 математики Російської Федерації. Так, одним з основних завдань початкової математичної освіти визначено: забезпечити оволодіння основами алгоритмічного мислення, записом i виконанням алгоритмів, умінням діяти відповідно до алгоритму і побудувати прості алгоритм. Одним із результатів основної загальної освіти $є$ набуття досвіду планування і здійснення алгоритмічної діяльності, виконання заданих і конструювання нових алгоритмів.

У характеристиці алгоритмічної діяльності учнів поряд із поняттям «алгоритмічне мислення» використовується і більш ширше поняття - «алгоритмічна культура». Більшість науковців поняття алгоритмічної культури трактують як комплекс особистісних якостей і певний рівень алгоритмічного мислення, які забезпечують:

1) розуміння ролі алгоритмів у різних видах діяльності;

2) уміння діяти за заданим алгоритмом (у розгорнутій чи згорнутій формі);

3) уміння здійснювати вибір і застосовувати алгоритми у своїй діяльності;

4) уміння конструювати алгоритми;

5) уміння описувати спосіб розв'язувати задачі у вигляді алгоритмічного припису.

Психологічні основи засвоєння алгоритмів. У сучасній психології інтегративним показником засвоєння знань, способів дій, діяльностей розглядаються уміння - «здатність належно виконувати певні дії, заснована на доцільному використанні набутих знань i навичок. Уміння передбачає використання раніше набутого досвіду; без останнього немає вмінь» [2, с. 338]. Отже, знання, навички, досвід - структурні компоненти уміння. Знання суб'єкта - це інформація, зафіксована на внутрішньо-суб'єктних носіях у постійній його пам'яті [1]. Навички - дії, складові частини яких у процесі формування стають автоматизованими.

Практико-орієнтована концепція засвоєння процедурної (алгоритмічної), діяльності розроблена Т. Габай [1]. Базується окреслена концепція на теоретичних положеннях С. Рубінштейна про формування умінь та на теорії поетапного формування розумових дій П. Гальперіна. Т. Габай теоретично обгрунтовує виокремлення трьох стадій формування процедурних (алгоритмічних) умінь.

Перша стадія (розуміння; початкове уміння) - ознайомлення, усвідомлення алгоритму діяльності, його смислу, простеження в полі сприйняття виконання дії вчителем, первинне виконання дії з опорою на матеріальні носії знань про алгоритм, спосіб дії, схему орієнтувальної основи дії; дії можуть виконуватися з найпростішими типами об'єктів і не у всій повноті своїх операцій, а тільки деякими з них найбільш суттєвими («напівфабрикати»). Основне призначення першої стадії формування орієнтувальної основи діяльності, вироблення уявлення образу способу дії чи діяльності.

Друга стадія (засвоєння; сформоване уміння) - готовність виконувати дію чи діяльність без спрямовуючих вказівок інших чи зовнішніх матеріальних носіїв інформації про їх алгоритми.

Із сформованим умінням виконувати дію (чи діяльність) визначеного предметного змісту позв'язують можливість ії здійснення суб'єктом при актуалізації в нього відповідної потреби і за наявності відповідної ситуації. Це передбачає такий компонентний склад уміння:

1) наявність у постійній пам’яті суб'єкта інформації про можливі типи ситуацій, суттєві для певної діяльності, та готовність iï використати шляхом актуалізації відповідних образів (чи без неї);

2) можливість реалізації всіх варіантів способу діяльності чи дії; можливість розпізнавання будь-якої наявної ситуації з віднесенням iї до однієї з категорії значимих для цієї діяльності;

3) можливість переходу від факту наявності тієї чи іншої ситуації до реалізації адекватного їй варіанту способу діяльності.

Третя стадія (оволодіння; досконале уміння) - здатність оперувати сформованими (засвоєнням) уміннями в складі діяльності, відмінної від ситуацій з'ясування і засвоєння - у 
змінених і нових. У таких ситуаціях головною, визначальною є не алгоритмічна, а пошукова діяльність, спрямована на знаходження способів, планів розв'язання задач, зведенням до відомих типових алгоритмічних задач чи їх послідовності або продукування нових способів розв'язань задач. Водночас реалізація знайдених планів, способів розв'язання задач переважно є алгоритмічною діяльністю - послідовним застосуванням відомих алгоритмів. Отже, на третій стадії збагачується досвід алгоритмічної діяльності, сформовані уміння закріплюються, вдосконалюються.

Дидактичні основи формування алгоритмічної компетентності учнів. За дидактичну основу формування алгоритмічної компетентності учнів, як і інших видів математичної компетентності, у дослідженні нами обрано модель поетапного оволодіння науковими знаннями, розроблену видатним чеським педагогом Я. Коменським, найбільш повно, цілісно викладену ним у роботі «Вихід із шкільних лабіринтів, або Дидактична машина...» [4]. Наголосимо на тому, що ця модель $\epsilon$ теоретичною основою чотирирівневої дванадцятибальної шкали оцінювання навчальних досягнень учнів. У розглядуваній моделі основною змістово-процесуальною одиницею, у якій здійснюється повний цикл навчання, $є$ навчальна тема. Навчальна тема $\epsilon$ цілісною системою знань про певний клас математичних об'єктів чи відношення між ними, їх властивості, ознаки та способи дій 3 ними. Зміст кожної теми поділяють на базовий зміст (базові елементи теорії і способи дій 3 об'єктами) та поглиблений. Засвоєння змісту здійснюється поетапно. Основним критерієм засвоєння знань $€$ їх застосування. На кожному етапі досягають системи результатів - певного рівня засвоєння теми, який є основою успішного навчання на подальших етапах.

Зміст поетапного вивчення теми за класичною моделлю викладений нижче.

Початковий етап (теорія; аналіз - за Я. Коменським).

1. Усвідомлення елементів базового теоретичного змісту (означень, аксіом, теорем, формул).

2. Осмислення елементів базового теоретичного змісту як згорнутих алгоритмів дій 3 об'єктами вивчення в темі.

3. Формування початкових умінь виконувати алгоритмічні дії.

Середній етап (практика, синтез).

1. Відтворення елементів базового теоретичного змісту.

2. Вироблення навичок виконання алгоритмічних дій із нескладними типами об'єктів.

3. Формування умінь розв'язувати базові алгоритмічні задачі з теми.

4. Розв'язування основних типових прикладних задач із застосуванням алгоритмічних процедур (алгоритмічні дії, алгоритмічні задачі).

Головний етап (застосування, міркування).

1. Відтворення доведень теорем базового змісту; обгрунтування базових алгоритмічних процедур.

2. Розв'язування стандартних задач на виконання алгоритмічних дій 3 об'єктами підвищеної складності.

3. Застосування базового змісту теми у змінених ситуаціях на основі нескладних аналітико-синтетичних міркувань; конструктивне зведення задач до базової алгоритмічної задачі або послідовності задач.

4. Застосування базового змісту в нових ситуаціях на основі нескладних аналітикосинтетичних міркувань; поглиблення базового змісту.

Завериальний етап (застосування; розмірковування).

1. Відтворення доведень теорем поглибленого змісту.

2. Розв'язування стандартних задач на виконання алгоритмічних дій 3 об'єктами високого рівня складності.

3. Застосування повного (базового й поглибленого) змісту, засвоєних алгоритмів у нових ситуаціях на основі ускладнених аналітико-синтетичних міркувань, евристик.

Структура й рівні математичної алгоритмічної компетентності та їх вимірники, розроблені у відповідності з викладеними теоретичними основами, подано нижче. 
Структура математичної алгоритмічної компетентності:

1. Tun: предметна компетентність.

2. Предметна сфера компетениї: множини, числа; алгебраїчні об’єкти - рівняння, нерівності, функції; геометричні фігури.

3. Предметні знання: 1) знання знаково-символічних позначень, графічних зображень об'єктів предметної області алгоритму, їх стандартних виглядів, основних типів, видів; 2) знання аксіом, означень, теорем, формул - згорнутих формулювань алгоритмічних дій; 3) знання складу операцій алгоритмічної дії, послідовності їх виконання; 4) знання складу дій алгоритмічної задачі та послідовності їх виконання.

4. Предметні уміння: 1) уміння виконувати базові алгоритмічні дії на рівні автоматизованого здійснення складових операції; 2) уміння розв'язувати базові алгоритмічні задачі; 3) уміння перетворювати (реконструювати) задану ситуацію i зводити іiі до розв'язування типової алгоритмічної задачі або їх послідовностей; 4) уміння конструювати алгоритми в результаті продуктивної логічної діяльності; 5) уміння конструювати алгоритми в результаті продуктивної логіко-евристичної діяльності; 6) уміння складати алгоритмічні приписи за змістом теоретичного положення; 7) уміння описувати спосіб розв'язання задачі у формі розгорнутого алгоритму.

5. Досвід алгоритмічної діяльності: застосування алгоритмічних процедур у ситуаціях первинного засвоєння; варіативних, змінених ситуаціях; нових ситуаціях.

6. Способи діяльності: репродуктивної діяльності із запам'ятовування, відтворення алгоритмічних процедур (прийоми ефективного запам'ятовування змісту алгоритмічних дій, задач, послідовності виконання операцій чи дій); конструктивно-репродуктивної діяльності (логічні прийоми, міркування); продуктивної діяльності (евристики, пошукові прийоми, творчі процедури).

7. Смислові орієнтації, ичінності:

1) усвідомлення причини виникнення алгоритмів як потреби людини в збереженні вдалих послідовностей дій, що привели до розв'язання задачі, з метою їх повторного застосування і передавання іншим (основний мотиваційний компонент);

2) розуміння значимості алгоритму в різних сферах діяльності і в пізнанні як ефективного засобу, що гарантує досягнення запланованого результату;

3) усвідомлення основних властивостей алгоритму (масовості, детермінованості, результативності);

4) усвідомлення теорем, означень, формул як згорнутих алгоритмів дій iз математичними об'єктами;

5) орієнтації під час розв'язування задач на пошук загального способу (а не способу розв'язання тільки однієї задачі).

Рівні алгоритмічної компетентності та їх вимірники:

Початковий рівень алгоритмічної компетентності - поінформованість.

1. Упізнавання правильних формулювань (записів) теоретичних основ алгоритмічних дій - означень, теорем, правил, формул; упізнавання правильного припису алгоритмічної дії; упізнавання правильного алгоритмічного припису розв'язування типової задачі.

2. Розпізнавання правильних виконань алгоритмічної дії; розпізнавання правильного розв'язування типової алгоритмічної задачі.

3. Виконання алгоритмічної дії з опорою на матеріальні носії припису або зразки виконання розв'язання типової задачі з опорою на зразок (схему, припис).

Середній рівень алгоритмічної компетентності - функціональна грамотність.

1. Виконання алгоритмічних дій за елементами теорії базового змісту.

2. Розв'язування базових задач на послідовне виконання 2-3 алгоритмічних дій.

3. Розв'язування базових типових прикладних задач за зразком чи алгоритмом.

Достатній рівень алгоритмічної компетенції.

1. Виконання базових алгоритмічних дій з ускладненими типами об’єктів.

2. Розв’язування операційно-ускладнених основних алгоритмічних задач. 
3. Розв'язування задач, які зводяться на основі нескладних аналітико-синтетичних міркувань до типових алгоритмічних задач чи їх послідовності.

Високий рівень алгоритмічної компетентності.

1. Виконання базових алгоритмічних дій зі складними типами об'єктів.

2. Застосування систем алгоритмічних дій на виконавчому етапі розв'язування задач, спосіб розв'язування яких визначається на основі складних аналітико-синтетичних міркувань, евристик.

3. Складання алгоритмічних приписів виконання дій за елементами теорії поглибленого змісту.

4. Складання алгоритмів розв'язування задач підвищеного рівня складності.

Логічний аналіз понять алгоритм, алгоритмічна діяльність, алгоритмічне мислення, алгоритмічна культура дозволив цілісно, системно охарактеризувати математичну алгоритмічну компетентність, розробити іï структуру, а на основі концепції трьох фаз формування умінь та класичної моделі тематичного поетапного вивчення наук описати рівні алгоритмічної компетентності.

За аналогічною схемою буде здійснено аналіз і дослідницької компетентності. Загалом, розроблені структура й рівні понятійної, процедурної та дослідницької компетенції складають теоретичну основу планування результатів навчання - компетенцій із кожної теми курсів математики основної і старшої школи та розроблення їх вимірників.

\section{Література}

1. Габай Т. В. Педагогическая психология / Т. В. Габай. - М. : Академия, 2003. - 240 с. 2. Гончаренко С. У. Український педагогічний словник / Семен Устимович Гончаренко. - К. : Либідь, 1997. - 374 с. 3. Захарійченко Ю. О. Проект концептуального проведення в Україні зовнішнього незалежного оцінювання / Ю. О. Захарійченко, О. В. Школьний // Вісник ТІМО. - 2009. №9. - С. 5-29. 4. Коменський Я. А. Избранные педагогические сочинения: Том 2 / Я. А. Коменський М. : Педагогика, 1982. - С. 174-191. 5. Копаев А. В. Алгоритм как модель алгоритмического процесса [Электронный ресурc] / А. В. Копаев. - Режим доступа: URL: http: //www. rusedu.ru. 6. Лапчик М. П. Вычисления. Алгоритмизация. Програмирование / М. П. Лапчик. - М. : Просвещение, 1998. - 208 с. 7. Ляшенко О. І. Тест загальної навчальної компетентності як складова зовнішнього незалежного оцінювання абітурієнтів / О. І. Ляшенко, С. А. Раков, М. Зелман // Вісник ТІМО. - 2009. - №6. - С. 4 10. 8. Макаренков Ю. А. Что такое алгоритм? / Ю. А. Макаренков, А. А. Столяр. - Мн. : Нар. освіта, 1989. - 127 с. 9. Фридман Л. М. Логико-психологический анализ школьных задач / Л. М. Фридман. М. : Педагогика, 1977. - 207 с. 10. Хуторской А. В. Ключевые компетенции как компонент личностноориентированной парадигмы образования / А. В. Хуторской // Народное образование. - 2003. - №3. C. 58-64.

УДК 378.027

Л. П. Лисогор, асистент,

Криворізький педагогічний інститут ДВНЗ «Криворізький наџіональний університет»

\section{ВИКОРИСТАННЯ ТЕХНОЛОГІЙ КООПЕРАТИВНОГО НАВЧАННЯ НА ЛАБОРАТОРНИХ ЗАНЯТТЯХ $З$ ОСНОВ ПРИРОДОЗНАВСТВА (ЗООЛОГІї) У ВИЩІй ШКОЛІ}

Лисогор Л. П. Використання технологій кооперативного навчання на лабораторних заняттях 3 основ природознавства (зоології) у вищій школі.

У статті розглядаються питання технологій кооперативного навчання на лабораторних заняттях 3 зоології, які надають змогу змінювати форми діяльності студентів, зосереджувати увагу на головних питаннях заняття та сприяють досягненню ними високих результатів засвоєння знань.

Ключові слова: інноваційні методи навчання, творчі здібності, кооперативне навчання, навчання у співпраці. 